\title{
RELASI ORANGTUA-ANAK DAN KUALITAS HIDUP PENYANDANG SKIZOFRENIA
}

\section{PARENTS-CHILDREN RELATION AND SCHIZOPHRENIA QUALITY OF LIFE}

\author{
Sheilla Varadhila Peristianto \\ Universitas Mercu Buana Yogyakarta \\ sheillavaradhila@gmail.com
}

\begin{abstract}
Abstrak
Anak yang mengalami skizofrenia tidak dapat berfungsi optimal dalam kehidupannya sehingga membutuhkan bantuan dari orang sekitar. Keberadaan anak justru sering dianggap berbahaya karena stigmasasi masyarakat. Orangtua pun menjadi kurang mendukung kesembuhan anak. Orangtua menyerahkan sepenuhnya penanganan anak pada petugas medis. Orangtua menampilkan ekspresi emosi yang tinggi pada anak yaitu berperilaku intrusive antara lain berlebihan, kejam, kritis dan tidak mendukung sehingga anak cenderung mengalami kekambuhan (Hasanat, 2004). Penelitian ini bertujuan untuk menggambarkan relasi orangtua dan anak, serta kualitas hidup anak penyandang skizofrenia. Subjek adalah orangtua yang memiliki anak penyandang skizofrenia. Relasi orangtua dan anak ditemukan peneliti pada saat wawancara di rumah sakit jiwa. Kualitas hidup anak penyandang skizofrenia diketahui menggunakan SQLS (Schizophrenia Quality of Life Scale) sebagai panduan observasi dan wawancara peneliti. Tulisan ini memberikan gambaran tentang relasi orangtua dan anak penyandang skizofrenia sebagai bagian dari faktor yang mempengaruhi kekambuhan gangguan yang dialaminya. Kurangnya kualitas dalam berkomunikasi sebagai salah satu tanda relasi orangtua dan anak penyandang skizofrenia. Kualitas hidup anak berupa perasaan kesepian, tidak memiliki teman, orang lain menghindari dirinya, serta kurang bersemangat untuk melakukan aktivitas.
\end{abstract}

Kata kunci : orangtua, skizofrenia, kualitas hidup

\begin{abstract}
Children with schizophrenia were not able to function optimally in life, therefore help from people surronding was needed. Children with schizophrenia was often considered harmful due to the stigma in society. Hence parental support for children's recovery was reduce. Parents hand over their children to medical staff and desert them. Parents also express intense emotions toward the children, such as intrusive behaviour i.e being mean, critical, exaggerative and unsuportive. Thus causes relapse for the children's (Hasanat, 2004). This research seeks to improve parents social support through SFT to recover the quality of life children with schizophrenia. Subjects of this research were the parents of children with schizophrenia. The schizophrenia quality of life was measured using SQLS (Schizophrenia Quality of Life Scale) as a guide to observe and intervewing. The results described about relation between parent with children with schizophrenia as a relapse factor. Lack of quality in communication as a sign relation between parent and children with schizophrenia. The quality of the child's life were feeling loneliness, had no friend, stigmatization, and less activity.
\end{abstract}

Keyword : parents, schizophrenia, quality of life.

\section{PENDAHULUAN}

Skizofrenia merupakan gangguan jiwa akut yang membuat pikiran, perasaan, dan perilaku seseorang menjadi tidak terkoordinasi. Penyandang skizofrenia umumnya mengalami ketidakmampuan mengendalikan secara nyata pada taraf kemampuan fungsionalnya dalam kehidupan sehari-hari sehingga cenderung memerlukan bantuan dan pertolongan pada pihak lain, 
khususnya kepada pihak keluarga. Keluarga sebagai relasi yang peduli terhadap seseorang yang mengalami suatu gangguan (Tenhula, Sadock, \& Sadock, dalam Kaplan, Sadock, \& Grebb, 2010).

Hendaya yang terjadi pada penyandang skizofrenia tidak dapat hilang begitu saja, banyak penyandang skizofrenia yang mengalami kekambuhan meskipun pernah dirawat oleh tenaga medis. Penyandang skizofrenia yang pernah dirawat di rumah sakit jiwa kambuh 50-80\% dari jumlah total (Rekam Medik RSJD Surakarta, 2014). Nasir dan Abdul (2011) menambahkan penyandang skizofrenia diperkirakan akan kambuh 50\% pada tahun pertama, 70\% pada tahun kedua, dan $100 \%$ pada tahun berikutnya. Kekambuhan terjadi karena adanya kejadian-kejadian buruk yang terjadi sebelum kambuh (Wiramihardja, 2007). Berdasarkan hasil observasi dan wawancara bulan Juli 2014 sampai Pebruari 2015 di Rumah Sakit Jiwa Daerah (RSJD) Surakarta, penyebab penyandang skizofrenia mengalami kekambuhan adalah karena perilaku keluarga khususnya orangtua. Interaksi yang kurang baik antara orangtua dan anak, seperti jarang mengajak berbicara anak, ketika mengajak berbicara pun dengan nada yang tinggi, dan mengejek atau menyindir anak apabila melakukan kesalahan. Setelah anak dinyatakan sembuh atau diperbolehkan pulang oleh pihak rumah sakit, beberapa bulan atau minggu bahkan beberapa hari setelahnya, anak kembali dirawat dengan alasan perilaku anak yang tidak dapat diterima oleh orangtua dan lingkungan sekitarnya.

Keterlibatan dalam proses pengasuhan terutama dalam penyembuhan anak dengan skizofrenia tidak hanya dari pihak rumah sakit. Proses penyembuhan sangat dipengaruhi oleh keterlibatan orangtua, khususnya dalam pemberian dukungan. Orangtua sendiri terdiri dari ayah dan ibu yang juga menjalankan peran sebagai suami-istri, sehingga hubungan komunikasi keduanya sangat turut mempengaruhi proses penyembuhan anak dengan skizofrenia.

Relasi suami istri menentukan warna bagi keseluruhan relasi di dalam keluarga (Lestari, 2012). Keberhasilan pasangan dalam keluarga adalah melakukan penyesuaian di antara pasangan, sedangkan penyesuaian ini sendiri bersifat dinamis dan memerlukan sikap dan cara berpikir yang luwes. Terdapat tiga indikator bagi proses penyesuaian sebagaimana diungkapkan Glenn (dalam Lestari, 2012), yakni konflik, komunikasi, dan berbagi tugas rumah tangga.

Penyesuaian yang berhasil ditandai oleh sikap dan cara dalam melakukan resolusi atas konflik yang terjadi dalam keluarga (Lestari, 2012). Relasi orangtua dan anak merujuk pada teori kelekatan (attachment theory) yang dicetuskan oleh John Bowlby. Bowlby (dalam Lestari, 2012) mengidentifikasikan pengaruh perilaku pengasuhan sebagai faktor kunci dalam hubungan orangtua dan anak yang dibangun sejak dini. Anak pada masa awal kehidupannya mengembangkan hubungan emosi yang mendalam dengan orangtua. Secara emosi, anak dapat merasa lekat dengan orangtua sehingga tidak ada batasan anak untuk menceritakan segala yang dialami dan dirasakan pada figur lekat yang seharusnya yaitu orangtua.

Chen (dalam Lestari, 2012) menjelaskan kualitas hubungan orangtua dan anak merefleksikan tingkat dalam hal kehangatan, rasa aman, kepercayaan, afek positif, dan 
ketanggapan. Kehangatan menjadi komponen mendasar dalam hubungan orangtua dengan anak yang dapat membuat anak merasa dicintai dan mengembangkan rasa percaya diri. Kehangatan juga memberikan konteks afeksi positif yang meningkatkan mood untuk peduli dan tanggap terhadap satu sama lain.

Perasaan hangat, dicintai oleh orangtua, dan percaya diri ini yang akan mempengaruhi proses penyembuhan dan meningkatkan kualitas hidupnya sebagai seorang manusia, meski telah menyandang skizofrenia sekalipun. Sandra, Rahayu, Munjiati (2009) menguatkan bahwa kualitas hidup berpengaruh terhadap keberfungsian anak dalam menjalankan aktivitas-aktivitas di kehidupan sosial.

Donald (dalam Irwansyah, Dhanu, \& Sjahrir, 2005) menyatakan kualitas hidup merupakan suatu terminologi yang menunjukkan tentang kesehatan fisik, sosial dan emosi individu serta kemampuannya untuk melaksanakan tugas sehari-hari. Chan dan Yeung (2008) menyatakan koping ketertarikan terhadap kualitas hidup pada penyandang skizofrenia dimulai dari proses deinstitusionalisasi yang terjadi tahun 1960 dan 1970 di negara-negara barat. Akibat dari reformasi kesehatan mental, adanya pergeseran dari perawatan rumah sakit jiwa (asylum) keperawatan yang berpusat kesehatan masyarakat, konsep kualitas hidup menjadi perlu bagi ahli klinis, peneliti, dan pembuat kebijakan dalam bidang kesehatan.

Pengukuran kualitas hidup skizofrenia ini penting dalam mengembangkan treatment yang dapat membantu penyandang skizofrenia untuk merasa terpenuhi dan puas dalam hidupnya. Dari berbagai penelitian sebelumnya juga dilaporkan bahwa penyandang skizofrenia memiliki kualitas hidup yang lebih rendah daripada populasi umum (Ristner \& Pinikaha, dalam Badli, Osman, \& Ainsah, 2008). Chan dan Yeung (2008) melihat kualitas hidup penyandang skizofrenia sebagai kesejahteraan dan kepuasan individu dengan keadaan hidupnya, status kesehatan, serta besarnya peluang dan kemudahan akses penyandang.

Gangguan skizofrenia yang menetap pada anak semakin lama dapat menurunkan kualitas hidup. Salah satu faktor penyebab terjadinya penurunan kualitas hidup penyandang skizofrenia adalah terjadinya kekambuhan karena kurangnya peran serta dukungan sosial yang diberikan orangtua dalam penanganan terhadap penyandang (Rubbyana, 2012). Orangtua justru memberi perlakuan yang kurang sesuai, seperti membatasi perilaku anak, khawatir berlebihan terhadap perilaku anak, dan anak tidak diperbolehkan keluar rumah (Keliat, 2006). Di sisi lain, orangtua merasa terbebani dengan kondisi anak sehingga memunculkan perasaan cemas ketika menghadapi anak, menjadi kurang sadar akan kebutuhan skizofrenia, dan tekanan dalam merawat, serta memunculkan stres yang ditampilkan orangtua dalam bentuk ekspresi emosi 'tinggi' (Vaughan \& Leff, 1985).

Kualitas hidup penyandang skizofrenia dipengaruhi oleh interaksi antara orangtua dengan anak. Maka dari itu tema tulisan ini "Relasi Orangtua-Anak, dan Kualitas Hidup Skizofrenia". Tulisan ini bertujuan untuk menggambarkan bentuk relasi antara orangtua dengan anak dan bentuk 
kualitas hidup anak penyandang skizofrenia. Diharapkan tulisan ini dapat bermanfaat bagi orangtua dan tenaga medis yang berkaitan dengan skizofrenia.

\section{METODE}

Metode yang digunakan untuk melihat gambaran relasi orangtua-anak dan kualitas anak penyandang skizofrenia adalah kualitatif deskriptif. Adapun tulisan ini berfokus pada bagaimana relasi orangtua-anak dan kualitas hidup anak skizofrenia. Peneliti menggunakan wawancara dengan guide skala Interpersonal Support Evaluation List untuk menggambarkan relasi orangtuaanak dan guide Schizophrenia Quality of Life Scale untuk menggambarkan kualitas hidup anak skizofrenia. Peneliti memberikan pertanyaan dan pengamatan pada subjek sesuai dengan aitemaitem dalam guide.

Gambaran relasi sosial menggunakan skala yang diadaptasi dari ISEL (Interpersonal Support Evaluation List) yang dikembangkan oleh Cohen \& Hoberman (1983). ISEL mencakup dimensi yang terdiri dari dukungan praktis, dukungan informasi, dukungan harga diri, dan dukungan akan rasa memiliki (Friedman, 2004; Cohen \& Hoberman, 1983). Alat ukur ISEL yang digunakan sebanyak 40 aitem, yang terdiri dari empat aspek, yang masing-masing berisi 10 aitem. Alat ukur ini dikembangkan dalam bentuk skala Likert berskala 3 yang termasuk dalam jenis skala ordinal, dengan menjumlahkan skor respon ya, kadang-kadang, dan salah.

Kualitas hidup anak diukur dengan skala SQLS (Schizophrenia Quality Of Life Scale) yang dikembangkan oleh Wild (2000) dengan cara melakukan observasi dan wawancara pada anak dan subjek. SQLS yang diadaptasi, mencakup tiga domain yang terdiri dari domain psikososial, motivasi dan energi dalam beraktivitas, serta simptom efek pengobatan. SQLS terdiri dari 30 aitem pernyataan yang masingmasing domain terdiri dari 10 aitem. Respon jawaban masing-masing aitem terdiri dari lima pilihan jawaban yaitu; tidak pernah, jarang, kadang-kadang, sering, dan selalu.

Peneliti melakukan expert judgement skala dukungan sosial dan kualitas hidup guna mendapat validitas isi pada beberapa ahli atau profesional yang terkait dengan penanganan skizofrenia, yaitu sebanyak 13 ahli. Ada pun 13 ahli tersebut antara lain; satu dosen doktor UMS, lima psikolog RSJD Surakarta, satu psikolog YPAC Surakarta, dua dokter praktek di RSJD Surakarta, dan dua fisioterapis RSJD Surakarta, serta dua perawat.

Jumlah subjek dalam penelitian ini adalah 6 subjek (3 pasang suami istri) dengan pendidikan minimal SMP, yang memiliki anak kandung dengan gangguan skizofrenia, usia anak 11-18 tahun, anak pernah dirawat inap lebih dari satu kali di Rumah Sakit Jiwa Daerah (RSJD) Surakarta. Data identitas subjek dijelaskan pada tabel 1. 
Tabel 1. Identitas Subjek Penelitian

\begin{tabular}{cccccccc}
\hline Subjek & Anak & Status & Usia & Pend & Pekerjaan & Anak & Diagnosis Anak \\
\hline SN & TY & Ayah & 47 th & SMP & Wiraswasta & TY & F20.3 Skizofrenia \\
SA & TY & Ibu & 49 th & SMP & Karyawan & & Tak Terinci \\
SR & AM & Ayah & 41 th & D3 & Wiraswasta & AM & F20.8 Skizofrenia \\
ST & AM & Ibu & 47 th & SMP & Karyawan & & Lainnya \\
SM & FW & Ayah & 47 th & SMP & Wiraswasta & FW & F20.0 Skizofrenia \\
DN & FW & Ibu & 42 th & SMA & IRT & & Paranoid \\
\hline
\end{tabular}

\section{HASIL DAN PEMBAHASAN}

Berikut ini dipaparkan gambaran relasi dalam keluarga subjek dan kualitas hidup anak skizofrenia.

\section{Hubungan di dalam keluarga 1 (SN, SA dan TY)}

SN dan SA mengalami kesulitan untuk merawat TY, mereka harus mencari tambahan dana dengan menjual tanah untuk berobat TY. SN dan SA juga bingung untuk berkomunikasi dengan TY yang sering diam ketika diajak berbicara. Ketika ada waktu luang, SA bertanya pada SN tentang apa yang dilakukan untuk merawat TY, mereka pun mencari solusi bersama seperti membawa TY ke orang pintar, sampai dengan menjual harta yang dimiliki seperti sepeda motor dan tanah yang dimiliki SA dan SN. SA dan SN secara bergiliran untuk mengontrolkan TY berobat apabila salah satunya ada yang berhalangan karena tidak dapat mengantar TY. SA memutuskan untuk menjaga TY di rumah sambil bekerja sebagai penjahit, sedangkan SN bekerja sebagai karyawati di sebuah pabrik dekat rumah.

Di dalam keluarga, SN dan SA berusaha untuk melibatkan TY dalam berbagai kegiatan. SN sering menyuruh TY untuk mengikuti kegiatan di masjid dekat rumah, membantu ibu berbelanja di pasar, serta mengajak TY untuk mencari pekerjaan, akan tetapi TY memilih diam sendiri di kamar. Di waktu luang, SN dan SA menceritakan keadaan yang dialami oleh TY yaitu tentang gangguannya dan menyampaikan rasa sayang orangtua ke anak. Hal tersebut dilakukan supaya TY berusaha untuk sembuh dari gangguan yang dialami. SA pun selalu memberikan pesan kepada TY untuk memasak nasi dan air ketika pagi, siang, dan sore, serta membantu SN menjahit, akan tetapi belum dilakukan TY. Ketika ditanya lebih mendalam SN pun belum bersedia untuk mengajari TY menjahit, karena mengaku kurang sabar apabila mengajari TY yang cenderung diam saja.

\section{Kualitas hidup anak (TY)}

Aspek psikososial, anak kadang merasa kesepian dengan hanya menyendiri di dalam kamar meski sedang tidak melakukan aktivitas. Anak sendiri terkadang merasa tidak enak hati dengan orang sekitar rumah karena merasa orang lain menghindari dirinya sehingga memilih tidak keluar rumah. 
"Ya gak pernah kok Mbak, tapi ya dia itu cuman merasa kesepian Mbak, ga punya teman. Di rumah ya sendiri saja di kamar. Gak mau ngapa-ngapain. Saya suruh ya ga mau apa- apa. Ya ga kenapa-kenapa sih. Emmm ya biarin saja Mbak, orang nanti dia ngamuk kalau em gitu. Dia itu hanya di dalam kamar saja seharian. Gak ngapa-ngapain. Sendiri saja. (TY yang keluar setelah dipanggil peneliti) Iya Mbak, saya di kamar saja (dengan suara lirih). Hehe ya em ga, sering Mbak. Kadang-kadang (dengan suara yang sangat pelan). Kadang-kadang Mbak ngerasa sepi gitu, ga ada yang diajak bicara hehehe tapi ya di kamar terus Mbak. Di situ. (sambil menunjuk ke kamar)" (W.S.A.I.1-23)

Aspek motivasi dan energi dalam beraktivitas, anak sering merasa kurang bertenaga atau bersemangat dan mudah capek saat melakukan aktivitas sehingga terlihat seperti akan jatuh sempoyongan. Anak juga tidak pernah terlihat melakukan aktivitas bahkan dilibatkan orangtua untuk beraktivitas bersama.

"Iya Mbak, TY itu ya lemah. Apa ya karena sakitnya ya Mbak? Ya gitu dia mudah capek, ga tenaga gitu. Sempoyongan. Oh begitu ya. Apakah pernah sampai jatuh gitu? Pernah Mbak, tapi ga sering. Seringnya cuman kayak mau jatuh. Em gak sih Mbak. Dikamar saja dia. Saya keburu-buru juga Mbak sudah harus kerja siangnya.”(W.S.A.I.27-40)

\section{Hubungan di dalam keluarga 2 (SR, ST, dan AM)}

Intensitas komunikasi di dalam keluarga SR dan ST dapat dikatakan kurang. Setiap harinya SR bekerja sebagai abdi dalem Keraton Surakarta, SR bekerja mulai pukul 08.00 sampai pukul 17.00. Hal tersebut membuat SR jarang berada di rumah dan berkomunikasi dengan ST dan AM. Sepulang dari bekerja, SR beristirahat dan mempersiapkan pekerjaan untuk keesokan hari. Sementara ST setiap harinya berada di rumah, yaitu memasak makanan untuk diantar ke warungwarung yang sudah memesan. Ketika di rumah SR dan ST jarang bercerita mengenai keadaan yang dialami oleh AM, dikarenakan SR merasa gangguan yang dialami oleh AM adalah kegagalan ST dalam menjaga AM di rumah. Sering kali SR dan ST berdebat, saling menyalahkan atas kondisi yang dialami AM. Terutama saat AM jadwal kontrol, SR dan ST merasa enggan untuk meninggalkan pekerjaannya masing-masing sehingga keduanya nampak saling 'lempar' tanggung jawab.

Meskipun setiap hari berada di rumah, ST merasa terpaksa harus menjaga AM. ST pun membiarkan AM berada di kamar meski tidak nampak beraktivitas. Apabila berbicara dengan AM, ST terdengar mengucapkan dengan nada tinggi, sehingga sering terjadi perdebatan antara ST dengan AM. Di sisi lain, AM bermaksud menceritakan keluhan yang dialami, namun karena tanggapan ST muncul dengan nada suara tinggi, maka AM pun menjawab pula dengan nada tinggi.

SR dan ST jarang melibatkan AM beraktivitas, seperti menyapu rumah, ataupun berjalanjalan ke luar rumah. Orangtua beralasan tidak sempat untuk melakukan hal tersebut. Bahkan 
sebagai orangtua, SR dan ST berusaha mencarikan pekerjaan yang bisa dijadikan tempat menginap untuk AM, supaya AM tidak menjadi hambatan di rumah.

\section{Kualitas hidup anak (AM)}

Pada aspek psikososial, anak hampir selalu merasakan kesepian dengan hanya menyendiri meski sedang tidak melakukan aktivitas di dalam kamar. Anak merasa tidak memiliki teman untuk sekedar bercerita. Anak juga hampir selalu merasa tidak dipedulikan keberadaanya dengan orangtua dan orang-orang sekitar rumah karena orang lain menghindari dirinya.

“Oh, em. Ya gak pernah kok Mbak, tapi ya dia diem. Dia cuman merasa kesepian Mbak, ga punya teman. Selalu kesepian. Gak punya teman untuk cerita. Di rumah menyendiri di kamar. Gak mau ngapa-ngapain. Saya ya sudah biarin. Ya sudah biarin sendiri Mbak. Ya ga kenapa-kenapa sih. Emmm. Ya biarin saja Mbak, orang nanti dia ngamuk kalau em gitu. Dia itu hanya di dalam kamar saja seharian. Oh ya, benar begitu ya Mbak AM? Iya Mbak, saya di kamar saja (dengan suara lirih). Seberapa sering merasakan kesepian Mbak? Hehe ya em ga, setiap hari Mbak. Emm iya. Ndak enak kok saya. Malu Mbak. Ndak enak hati saya Mbak, kalau dihindari." (W.S.A.II.120)

Pada aspek motivasi dan energi dalam beraktivitas, anak selalu merasa kurang bersemangat beraktivitas karena tidak mengerti yang harus dilakukan. Selain itu, anak masih cenderung dilarang untuk melakukan aktivitas, meskipun sederhana. Misalnya, anak tidak pernah dilibatkan dalam aktivitas rumah seperti menyapu laintai atau membersihkan rumah.

"Iya Mbak, AM itu ya lemah. Ya gitu dia mudah capek, ga tenaga gitu. Oh begitu ya sempoyongan. Dia ga semangat, ga mau melakukan apa-apa seperti masih ada yang ngelarang gitu Mbak. Terus gak tau yang mau dilakuin juga. Benar begitu ya Mbak AM? Apakah ada bentuknya. Ya kadang ga ada sih Mbak. Em gak sih Mbak. Di kamar saja dia. Saya keburu-buru juga harus cepet selesai. Iya ibunya ini emang ga sabaran kok." (W.S.A.II.21-37)

\section{Hubungan di dalam keluarga 3 (SM, DN, dan FW)}

SM dan DN merasa kesulitan untuk merawat FW yang mengalami gangguan skizofrenia. Keduanya mengeluhkan biaya yang banyak untuk biaya berobat FW. Selain itu muncul perasaan khawatir jika FW melakukan aktivitas yang berbahaya seperti mengkonsumsi alkohol dan berkelahi karena dampak dari gangguan yang tidak mampu dikendalikan. SM bekerja sebagai petugas parkir sehingga merasa tidak dapat mengawasi aktivitas FW di rumah, karena SM bekerja mulai pagi hingga sore hari. Sedangkan DN bekerja sebagai pembantu rumah tangga harian, sepulang bekerja DN segera mencari FW untuk mengingatkan waktu makan dan menyediakan obat. SM dan DN pun meminta bantuan nenek untuk menjaga FW di rumah. Terdengar nada suara keras dan tinggi saat SM berbicara dengan FW terutama ketika FW tidak berperilaku sesuai 
perintah SM. Sebaliknya, apabila FW bercerita tentang perasaannya, SM dan DN nampak kurang menanggapi dan justru menyalahkan FW.

Keluarga SM dan DN yang bertempat tinggal di rusun merasa kurang tenang dengan gangguan yang dialami oleh FW. SM takut apabila kambuh, FW mengamuk lalu mengancam membunuh adik-adiknya, seperti yang pernah dilakukan FW sebelumnya. Hal yang semakin membuat takut apabila perilaku kambuh FW tersebut diketahui oleh tetangga sekitar.

\section{Kualitas Hidup Anak (FW)}

Aspek psikososial, anak sering merasakan kesepian dengan hanya menyendiri. Anak terkadang merasa dihindari oleh orang lain sehingga memilih menghabiskan waktu di kamar.

"Gak pernah kok Mbak, tapi ya dia itu merasa kesepian Mbak, ga punya teman. Di rumah ya sendiri saja di rumah neneknya. Gak mau ngapa-ngapain. Saya suruh ya ga mau apa-apa. Selanjutnya apa yang Bapak Ibu lakukan ketika FW merasa kesepian? Ya ga kenapa-kenapa sih. Emmm. Ya biarin saja Mbak, orang nanti dia ngamuk kalau em gitu. Dia itu hanya tidur terus kerjaannya. Iya ya Mas FW? Hehehe lha biar ga dimarahin, ga disingkirin. Yasudah tidur di rumah nenek saja Hehe ya em setiap hari Mbak. Emm iya. Ndak enak kok saya. Takut kalau dihindari. Takut pada lari." (W.S.A.III.1-17)

Pada aspek motivasi dan energi dalam beraktivitas, anak sering merasa kurang bersemangat sehingga memilih untuk menyendiri di kamar dan tidur. Anak juga tidak pernah dilibatkan aktivitas rumah karena orangtua memiliki 'kesibukan' sendiri.

"Iya Mbak, FW hanya tidur saja itu. Ya gitu dia mudah capek, ga tenaga gitu. Seperti gak ada semangat. IyaEm gak sih Mbak. Tidur saja dia. Sore gitu baru nongkrong sama temennya. Ngerokokan.” (W.S.A.III.18-30)

Relasi orangtua dan anak merujuk pada teori kelekatan (attachment theory) yang dicetuskan oleh John Bowlby. Bowlby (dalam Lestari, 2012) mengidentifikasikan pengaruh perilaku pengasuhan sebagai faktor kunci dalam hubungan orangtua dan anak yang dibangun sejak dini. Anak pada masa awal kehidupannya mengembangkan hubungan emosi yang mendalam dengan orangtua. Seharusnya anak dapat merasa lekat secara emosi dengan orang tua sehingga tidak ada batasan anak untuk menceritakan segala yang dialami dan dirasakan pada figur lekat yaitu orangtua. Akan tetapi berdasarkan temuan awal penelitian yang juga mendukung penelitian sebelumnya, dukungan keluarga mempengaruhi perawatan penyandang skizofrenia di Instalasi Rawat Jalan Rumah Sakit Jiwa Provinsi Jawa Barat. Sebagian responden yaitu sebanyak 48,96\% memberikan dukungan dalam perawatan penyandang skizofrenia dan sebagian responden sebanyak $51,04 \%$ tidak memberikan dukungan dalam perawatan penyandang skizofrenia. Dukungan emosional menjadi persentasi tertinggi keluarga tidak memberikan dukungan sosial dalam perawatan penyandang skizofrenia. 
Permasalahan dukungan orangtua adalah aspek emosi yaitu harga diri dan rasa akan memiliki orangtua. Orangtua telah memenuhi kebutuhan sehari-hari anak seperti makan, minum, tidur, dan pakaian, akan tetapi dukungan yang lebih mendalam yaitu emosi justru tidak diberikan. Oleh sebab itu, kurang terbentuk kelekatan anak secara emosi misalnya orangtua kurang memberikan perhatian dan peka atas perasaan anak. Perilaku yang dimunculkan, anak menjadi tidak dapat bercerita mengenai perasaannya, sehingga memilih menyendiri dan tertutup sampai saat ini. Hal tersebut terjadi sama pada keluarga I, II, dan III, serta berdampak sama pada anak yang cenderung menyendiri yaitu TY, AM, dan FW.

Chen (dalam Lestari, 2012) menjelaskan kualitas hubungan orangtua dan anak merefleksikan tingkat dalam hal kehangatan, rasa aman, kepercayaan, afek positif, dan ketanggapan. Kehangatan menjadi komponen mendasar dalam hubungan orangtua dengan anak yang dapat membuat anak merasa dicintai dan mengembangkan rasa percaya diri. Kehangatan juga memberikan konteks afeksi positif yang meningkatkan mood untuk peduli dan tanggap terhadap satu sama lain.

Pada seluruh orangtua I, II, dan III tidak memunculkan kelekatan emosi dalam hal kehangatan sebagai komponen dasar untuk membentuk hubungan orangtua dengan anak. Sehingga anak merasa tidak dicintai dan mengembangkan rasa mindernya terhadap anak-anak lain. Anak TY, AM, dan FW merasa teman-teman lebih mampu dalam segala hal dan memiliki banyak teman sehingga anak justru semakin memilih menyendiri. Sikap anak yang menyendiri membuat dirinya mendapat 'ejekan' dari lingkungan sehingga semakin menguatkan. Tidak adanya kehangatan juga menjadikan orangtua kurang tanggap atas apa yang terjadi pada anak, sehingga orangtua memilih membiarkan berlalu. TY, AM, dan FW memilih semakin tertutup. Orangtua II yaitu SR dan ST, serta orangtua III yaitu SM dan DN memilih membiarkan berlalu atas cerita anak sehingga anak merasa orangtua tidak menanggapinya. Semakin tidak terbentuklah kehangatan antar orangtua dan anak.

Sikap orangtua kurang memberikan kehangatan dan penglibatan dalam aktivitas menjadikan anak menjadi termotivasi sehingga aspek psikososial anak menurun. Anak merasa orangtua 'jauh' dan kurang mendukung kesembuhan. Sebaliknya, orangtua yang memberikan kasih sayang dan kehangatan serta penglibatan dan pemberdayaan anak terhadap aktivitas sehari-hari di rumah menjadikan anak aspek motivasi dan psikososial anak meningkat. Anak lebih termotivasi dan bersemangat untuk melakukan aktivitas serta tidak lagi merasakan kesepian karena memahami orangtua yang senantiasa berada di dekatnya untuk mendukung kesembuhan. Orangtua dan anak merasa peduli satu sama lain untuk lebih tertuju dalam proses penyembuhan anak. Kasih sayang dan kehangatan orangtua sejalan dengan konsep ngemong sangat penting sebagai salah satu bentuk dari dukungan orangtua (Subandi, 2008). Sikap toleran, tidak mencela, dan tidak menuntut yang ditunjukkan dalam konsep ngemong sejalan dengan kriteria Expressed Emotion yang 'rendah' 
(Hasanat, 2004). Expressed Emotion 'rendah' diketahui sebagai salah satu faktor yang dapat mencegah kekambuhan dari gangguan skizofrenia.

\section{KESIMPULAN}

Berdasarkan penelitian yang telah dilakukan, maka dapat diketahui bahwa relasi antara orangtua dan anak pada seluruh keluarga berupa kurangnya kualitas komunikasi orangtua dengan anak. Orangtua merasa sibuk bekerja sehingga membiarkan anaknya beraktivitas sendiri, orangtua juga bingung untuk mengajak anak berkomunikasi pada akhirnya justru jarang mengajak anak berbicara. Anak tidak dilibatkan dalam kegiatan yang mudah pada kehidupan sehari-hari, anak berdiam diri di dalam kamar dan enggan melakukan aktivitas rumah tangga yang sederhana. Kualitas hidup anak penyandang skizofrenia berupa perasaan kesepian, merasa tidak memiliki teman, merasa orang lain menghindari dirinya, serta kurang bersemangat untuk melakukan aktivitas yang ditunjukkan dengan perilaku tidur dan bermalas-malasan di dalam kamar.

Kepada orangtua, diharapkan menambah wawasan mengenai gangguan skizofrenia dengan mencari informasi dari berbagai sumber seperti internet, dokter, psikolog, dan perlu juga membentuk kelompok diskusi (orangtua yang memiliki anak skizofrenia) sebagai tempat berbagi pengalaman dan pengetahuan.

\section{DAFTAR PUSTAKA}

Badli, M., Osman, O., \& Ainsah. (2008). Coping Styles and Clinical Factors in Relation to Quality of Life among Patiens with Schizophrenia. Med \& Health, 3 (1), 14-21.

Chan, W. S. H. \& Yeung, C. (2008). Path Model of Quality of Life Among People with Schizophrenia Living in the Community in Hongkong. Community Mental Health Journal, 44, 97-112.

Hasanat, N. U. (2004). Expressed emotion pada keluarga penderita gangguan jiwa. Buletin Psikologi, 12 (2), 85-91.

Irwansyah, S., Dhanu, R., \& Sjahrir, H. (2005). Hubungan antara Disabilitas dengan Kualitas Hidup pada Penyandang Nyeri Kepala Primer yang berobat jalan di Departemen Neurologi FK US U/RSUPH Adam Malik Medan. Majalah Kedokteran Nusantara, 38 (4), 296-301.

Kaplan H. I., Sadock B. J., and Grebb J. A. (2010). Sinopsis psikiatri jilid 2. Terjemahan Widjaja Kusuma. Jakarta: Binarupa Aksara.

Keliat, B. A. (2006). Proses Keperawatan Kesehatan Jiwa Edisi 2. Jakarta: EGC.

Lestari, S. (2012). Psikologi Keluarga: Penanaman Nilai dan Penanganan Konflik Keluarga. Jakarta: Kencana Prenada Media Group.

Nasir, A. \& Abdul, M. (2011). Dasar-dasar Keperawatan Jiwa, Pengantar dan Teori. Jakarta: Salemba Medika.

Rekam Medik. (2014). Rumah Sakit Jiwa Daerah Surakarta. 
Rubbyana, U. (2012). Hubungan antara Strategi Koping dengan Kualitas Hidup pada Penderita Skizofrenia Remisi Simptom. Jurnal Psikologi Klinis dan Kesehatan Mental, 1 (2).

Sandra Pebrianti, Rahayu Wijayanti, dan Munjiati. 2009. Hubungan Tipe Pola Asuh Keluarga dengan Kejadian Skizofrenia Di Ruang Sakura RSUD Banyumas. Jurnal Keperawatan Soedirman The Soedirman Journal of Nursing. Volume 4 No.1 Maret 2009

Subandi, M. A. (2008). Ngemong: Dimensi keluarga pasien psikotik di Jawa. Jurnal Psikologi Fakultas Psikologi Universitas Gadjah Mada, 35 (1), 62-79.

Vaughan, C. \& Leff, J. (1985). Expressed emotion in families. United States of America: The Guildford Press.

Wiramihardja, A. S. (2007). Pengantar Psikologi Klinis. Bandung: PT. Refika Aditama. 